\title{
THE WORSHIP OF DIVINE MERCY IN LIGHT OF THE TEACHING OF POPE BENEDICT XVI AND POPE FRANCIS
}

\begin{abstract}
A b s t r a c t. The two most recent Popes - Benedict XVI and Francis - have continued John Paul II's emphasis on Divine Mercy. Each provides a particular emphasis, which results in a different manner of worshipping Divine Mercy. While each emphasize the entirety of salvation history as revealing Divine Mercy, with its climax in Jesus Christ, Pope Francis more often speaks of mercy so as to avoid a theory of mercy that is not put into practice. One such manner of implementing mercy is the addition of new mysteries of mercy to the Rosary. While this has no support from the papal magisterium of Pope Benedict, it does find support in Pope Francis' desire to find ways for mercy to penetrate ever more into the daily attitudes and actions of Christians. Even so, care must be taken to frame such a change in the veneration of Divine Mercy within a proper theology that highlights the presence of Divine Mercy in the pre-existing mysteries, particularly that the Incarnation and the Paschal Mystery.
\end{abstract}

Key words: Divine Mercy; worship; veneration; devotion; Benedict XVI; Francis; Rosary.

\section{INTRODUCTION}

Pope Benedict XVI stated that Divine Mercy is the privileged key to the interpretation of the entire pontificate of John Paul II. ${ }^{1}$ Not only did he write

Thaddaeus Lancton MIC, currently assigned to Vinto, Cochabamba, Bolivia; e-mail: thaddaeusmic@gmail.com; ORCID: http://orcid. org/0000-0003-3807-9757.

1 Benedict XVI, "Holy Mass on the Third Anniversary of the Death of the Servant of God John Paul II (2.4.2008)," in Homilies of Pope Benedict XVI (English) (Vatican City: Libreria Editrice Vaticana, 2013): "God's mercy, as he himself said, is a privileged key to the interpretation of his Pontificate. He wanted the message of God's merciful love to be made known to all and urged the faithful to witness to it." 
on Divine Mercy, ${ }^{2}$ he also named the Second Sunday of Easter as Divine Mercy Sunday in 2001. ${ }^{3}$ In addition, he issued a plenary indulgence for those who participate in Divine Mercy Sunday, with specific requirements. ${ }^{4}$ Notable is that his papal magisterium is based largely upon the Bible and Tradition, whereas in his promotion of new forms of worship, he relies more directly upon private revelations. ${ }^{5}$

The law lex orandi, lex credendi implies an explicit correspondence between the manner of worship and what is believed by the faithful. Certain consequences regarding forms of worship flow from theology of Divine Mercy. In other words, the forms of worship of Divine Mercy depend upon the understanding or concept of Divine Mercy. As the proclamation of Divine Mercy has continued in the pontificates of both Benedict XVI and Francis, this article examines the most salient aspects of their papal magisterium on Divine Mercy so as to highlight the forms of worship compatible with such teaching. One current proposal is to add mysteries of mercy to the Rosary, in imitation of addition of the mysteries of light. Such an addition was made precisely in light of a deepened theology of the Rosary as a contemplation of Christ. ${ }^{6}$ This article thus examines the theology and worship of Divine Mercy in light of this proposal.

\section{ANALYSIS OF THE TEACHING OF BENEDICT XVI ON DIVINE MERCY}

Pope Benedict does not frequently refer to mercy in his encyclicals. For example, the word mercy is mentioned only once in Deus Caritas Est. ${ }^{7}$ In Caritas

2 Cf. John Paul II, Encyclical Dives in Misericordia (Vatican: Libreria Editrice Vaticana, 1980).

${ }^{3}$ Cf. Congregation for Divine Worship and the Discipline of the Sacraments, Decree Establishing the Sunday after Easter "Divine Mercy Sunday" (Vatican: Libreria Editrice Vaticana, 2000).

${ }^{4} \mathrm{Cf}$. Apostolic Penitentiary, Decree Indulgences attached to devotions in honour of Divine Mercy (Vatican: Libreria Editrice Vaticana, 2002).

${ }^{5}$ Cf. Faustina Kowalska Sr., Divine Mercy in My Soul (Stockbridge: Marian Press, 1987). Cf. John Paul II, "Homily Divine Mercy Sunday (22.4.2001)," in Homilies of Pope John Paul II (English) (Vatican City: Libreria Editrice Vaticana, 2014), 22 April 2001.

6 John Paul II, Apostolic Letter Rosarium Virginis Mariae (Vatican: Libreria Editrice Vaticana, 2002), nr. 5, 10-13.

7 Cf. Benedict XVI, Encyclical Deus Caritas Est (Vatican: Libreria Editrice Vaticana, 2005), nr. 25, in reference to the bishop's promise to aid the poor. The encyclical nevertheless touches upon the reality of mercy as caritas, which is expressed in service to those in need (diakonia), which includes the proclamation of the Gospel of merciful love (keygma-martyria), which in turn is received and experienced in the liturgy (leitourgia). Cf. Benedict XVI, Encyclical Deus Caritas Est, nr. 32. 
in Veritate, the word "mercy" appears only twice. ${ }^{8}$ In Spe Salvi, suffering becomes bearable through hope in the Lord's mercy, that is, the gracious gift of divine love in Christ. ${ }^{9} \mathrm{He}$ is with man in the solitude of his suffering and accepts man's suffering in His own flesh. God cannot suffer but Jesus has suffered with man on the Cross, which is the supreme act of mercy and compassion. Consolation and compassion are the mode of mercy for each Christian, called upon to willingly share another's suffering. ${ }^{10}$

Sacramentum Caritatis states that certain rites of the Mass that focus on personal sin are to be highlighted so as to heal the the loss of consciousness of $\sin$ that results in a superficial understanding God's mercy. ${ }^{11}$ Calling upon God "in his mercy" results in the gift of the Holy Spirit who transforms the gifts of bread and wine into the body and blood of Christ. ${ }^{12}$ The Eucharist furthermore is to be brought to prisoners, since they need to be personally visited by the Lord. ${ }^{13}$ Verbum Domini states that the Word of God grants man the light to recognize his sins, calls him to conversion and inspires within him confidence in God's mercy. ${ }^{14}$ In addition, women are "models of mercy and peacemakers," communicating "warmth and humanity" in a world that judges others according to "exploitation and profit." 15

More explicit references to Divine Mercy are found in Pope Benedict's homilies and audiences. For instance, he described mercy as the "central nucleus of the Gospel message" and the very "name of God, the Face with which he revealed himself in the Old Covenant and fully in Jesus Christ, the incarnation of creative and redemptive Love." ${ }^{\prime 16}$ Grace and fidelity, mercy and truth, are the names of God by which He is made known to every people; they are the content of God's glory

${ }^{8}$ Cf. Benedict XVI, Encyclical Caritas in Veritate (Vatican: Libreria Editrice Vaticana, 2009). Authentic development of the earthly city is promoted by "relationships of gratuitousness, mercy, and communion," (nr. 6) and "reliance upon God's providence and mercy, love and forgiveness [...]" (nr. 79).

9 Cf. Benedict XVI, Encyclical Spe Salvi (Vatican: Libreria Editrice Vaticana, 2007), nr. 37. Explicit references to mercy are found within the story of the martyr Paul Le-Bao-Tinh, who praises God for his mercy even amid terrible suffering.

${ }^{10}$ Cf. Benedict XVI, Encyclical Spe Salvi, nr. 37-39.

${ }^{11}$ Benedict XVI, Apostolic Exhortation Sacramentum Caritatis (Vatican: Libreria Editrice Vaticana, 2007), nr. 20.

${ }^{12}$ Benedict XVI, Apostolic Exhortation Sacramentum Caritatis, nr. 13.

${ }^{13}$ Ibidem, nr. 59.

${ }^{14}$ Benedict XVI, Apostolic Exhortation Verbum Domini (Vatican: Libreria Editrice Vaticana, 2010), nr. 61.

${ }^{15}$ Ibidem, nr. 85.

${ }^{16}$ Benedict XVI, "Regina Caeli Second Sunday of Easter (30.3.2008)," in https://w2.vatican. va/content/benedict-xvi/en/angelus/2008/documents/hf_ben-xvi_reg_20080330.html. Cf.: 
revealed to every nation. ${ }^{17}$ The culmination of salvation history and the supreme sign of the Father's merciful love is the gift of his Son in the Incarnation. ${ }^{18}$ The mystery of Christmas frees man from fear, enabling him to love rather than fear God. ${ }^{19}$ By contemplating God made flesh, man is transformed by His mercy. ${ }^{20}$

The Face of Christ, the merciful Lord, ${ }^{21}$ is the "supreme revelation of God's mercy." 22 The constant contemplation of this Face (cf. 2 Cor 3:18) is the legacy entrusted to each Christian, which one ought to welcome and make one's own. Merciful love is to shine on the face of the Church through sacraments (particularly Reconciliation) and works of charity. All that the Church proclaims and does is to be a manifestation of Divine Mercy that is the key to peace within men's hearts and in the world, ${ }^{23}$ for Divine Mercy alone illumines the mystery of man. ${ }^{24}$

Divine omnipotence does not negate man's freedom, since God guards man's freedom and provides him all that is necessary for life. ${ }^{25}$ For the summit

Robert Stackpole, Divine Mercy: A Guide from Genesis to Benedict XVI (Stockbridge: Marian Press, 2008), 255-262.

${ }^{17}$ Benedict XVI, "Homily, Cappella Papale on the Solemnity of the Epiphany (6.1.2006)", in Homilies of His Holiness Benedict XVI (Vatican City: Libreria Editrice Vaticana, 2013).

${ }^{18}$ BenEDICT XVI, "Audience Psalm 135, 10-26 «To the God of Heaven give thanks» Evening Prayer - Monday of Week Fourth (16.11.2005)," in Audiences of His Holiness Benedict XVI (Vatican City: Libreria Editrice Vaticana, 2013). Cf. Benedict XVI, "Audience The meaning of Christmas (20.12.2006): "At holy Christmas we will relive the fulfillment of this sublime mystery of grace and mercy»," in Audiences of His Holiness Benedict XVI (Vatican City: Libreria Editrice Vaticana, 2013); Benedict XVI, “Audience Spiritual meaning of Christmas (17.12.2008)," in: Audiences of His Holiness Benedict XVI (Vatican City: Libreria Editrice Vaticana, 2013).

${ }^{19}$ Benedict XVI, “Audience St. Theresa of Lisieux (6.04.2011)," in Audiences of His Holiness Benedict XVI (Vatican City: Libreria Editrice Vaticana, 2013): "In her last Letter, on an image that represents Jesus the Child in the consecrated Host, the Saint wrote these simple words: «I cannot fear a God who made himself so small for me! [...] I love him! In fact, he is nothing but Love and Mercy!»"(LT 266).

${ }^{20}$ Benedict XVI, "Audience (22.12.2010)," in The Audiences of His Holiness Benedict XVI (Vatican City: Libreria Editrice Vaticana, 2013).

${ }^{21}$ Benedict XVI, "Audience World Youth Day in Cologne (24.8.2005)," in The Audiences of His Holiness Benedict XVI (Vatican City: Libreria Editrice Vaticana, 2013).

${ }^{22}$ BenEDICT XVI, "Regina Caeli Second Sunday of Easter (30.3.2008)," in Divine Mercy: A Guide from Genesis to Benedict XVI, edited by Robert Stackpole (Stockbridge: Marian Press, 2008).

${ }^{23}$ Benedict XVI, "Regina Caeli Second Sunday of Easter (30.3.2008)."

${ }^{24}$ Benedict XVI, "Audience Apostolic Journey to Poland «Stand firm in your faith!» (31.5.2006)," in The Audiences of His Holiness Benedict XVI (Vatican City: Libreria Editrice Vaticana, 2013). "My next stop, at the Shrine of Divine Mercy in Lagiewniki, gave me the opportunity to stress that Divine Mercy alone illumines the mystery of man [...]."

${ }^{25}$ Benedict XVI, "Homily Celebration of Vespers with the Faithful of Aosta (24.7.2009)," in The Homilies of His Holiness Benedict XVI (Vatican: Libreria Editrice Vaticana, 2013): "Whoever has power and many worldly effects may be dangerous, as he could threaten and destroy. But Revelation 
of God's power is mercy and pardon. ${ }^{26}$ God reveals His merciful power, his full salvific force, as at the Red Sea, to save His People. ${ }^{27}$ Mercy is God's power, acting as a divine barrier against the evil of the world. ${ }^{28}$ Only Divine Mercy, the omnipotence of divine love, places a limit upon evil and defeats its tyranny. ${ }^{29}$ The summit of God's power is manifest in the Cross, in His ability to suffer with man, as the answer to man's suffering. ${ }^{30}$ Man can ask God why He allows suffering; even then, it is important to place trust in God, as did the Jews during the Babylonian exile. ${ }^{31}$ Benedict XVI describes Psalm 123 precisely as a prayer of expectation for mercy, that the divine hands will act justly and destroy evil, delivering His people in their plight. ${ }^{32}$

Even in suffering, God is with us through Christ crucified, granting us consolation amid our difficulties, in which man can have certainty and hope because God always reaches out to man first. ${ }^{33}$ Christ teaches that even in death, man never falls from God's hands that create, sustain, and accompany him, since man is guided by His infinite and faithful Love. ${ }^{34}$ For evil is definitively overcome by the cruci-

tells us «It is not so,»; true power is the power of grace and of mercy. In his mercy, God demonstrates true power [...] The summit of God's power is mercy, pardon."

${ }^{26}$ Cf. The Roman Missal, Third Typical Edition (Washington: International Commission on English in the Liturgy, 2011) (Collect for $26^{\text {th }}$ Sunday of Ordinary Time). Cf. Thomas Aquinas, Summa Theologiae, I, q. 21, a. 3; II-II, q. 30. a. 4.

${ }^{27}$ Benedict XVI, "Audience The Great Hállelo Psalm 136 (135) (19.10.2011)," in The Audiences of His Holiness Benedict XVI (Vatican: Libreria Editrice Vaticana, 2013): "At the Red Sea too the Lord acted with merciful power [...]."

${ }^{28}$ Benedict XVI, “Audience Apostolic Journey to Poland «Stand firm in your faith!» (31.5.2006),” in The Audiences of His Holiness Benedict XVI (Vatican: Libreria Editrice Vaticana, 2013).

${ }^{29}$ Benedict XVI, "Homily Holy Mass on the Third Anniversary of the Death of the Servant of God John Paul II (2.04.2008)," in Homilies of His Holiness Benedict XVI (Vatican: Libreria Editrice Vaticana, 2013): "In fact, only Divine Mercy is able to impose limitations on evil; only the almighty love of God can defeat the tyranny of the wicked and the destructive power of selfishness and hate."

${ }^{30}$ Benedict XVI, "Homily Celebration of Vespers with the Faithful of Aosta (24.07.2009)," in The Homilies of His Holiness Benedict XVI (Vatican: Libreria Editrice Vaticana, 2013): "This is the summit of his power, that he can suffer with us. In this way he demonstrates the true divine power: he desired to suffer with us and for us. In our suffering we are never left alone."

${ }^{31}$ Benedict XVI, "Homily Holy Mass at Touristic Airport, Freiburg im Breisgau (25.09.2011)," in The Homilies of His Holiness Benedict XVI (Vatican: Libreria Editrice Vaticana, 2013).

32 Benedict XVI, “Audience Psalm 123 [122] «Have mercy on us» Evening Prayer - Monday of Week Three (15.06.2005)," in The Audiences of His Holiness Benedict XVI (Vatican City: Libreria Editrice Vaticana, 2013).

${ }^{33}$ Benedict XVI, "Audience (30.05.2012)," in The Audiences of His Holiness Benedict XVI (Vatican City: Libreria Editrice Vaticana, 2013): "Instead, God does not grow tired of us; he never wearies of being patient with us and, with his immense mercy, always leads the way and reaches out to us first: his «yes» is absolutely reliable."

${ }^{34}$ Benedict XVI, "Audience (15.02.2012)," in The Audiences of His Holiness Benedict XVI (Vatican City: Libreria Editrice Vaticana, 2013). 
fied and risen Christ: his triumph is expressed by the power of merciful love. His Resurrection provides the certainty that evil never has the last word. ${ }^{35}$

The merciful love of God is made manifest on the Cross, inasmuch as it symbolizes the grace given to every creature freely and is the place of contact between human sinfulness and Divine Mercy ${ }^{36}$ The Cross is the instrument of salvation that reveals the mercy and compassion of God in all its fullness, ${ }^{37}$ the revelation of his love that does not count the cost and has no limits. ${ }^{38}$ God Himself enters into the world to overcome the ocean of sin and injustice with a larger ocean of goodness and of love flowing from the pierced heart of Christ. ${ }^{39}$ Confession is a celebration of Divine Mercy at the Cross, where each person can experience the gratuitous gift of God that infuses His divine life into man to heal him of sin and sanctify him. ${ }^{40}$ Such divine forgiveness indicates that God transforms, rather than ignores, the present reality.

The vocation to priesthood is also a mystery of mercy: the mission of priests is to be a sign and presence of God's infinite mercy. ${ }^{41}$ One of the most precious

\footnotetext{
${ }^{35}$ BenEDICT XVI, "Audience From darkness to light! (12.04.2006)," in The Audiences of His Holiness Benedict XVI (Vatican City: Libreria Editrice Vaticana, 2013).

${ }^{36}$ Benedict XVI, "Audience St. Paul (10): The Importance of Christology: the Theology of the Cross (29.10.2008)," in The Audiences of His Holiness Benedict XVI (Vatican City: Libreria Editrice Vaticana, 2013). Cf. Benedict XVI, “Audience St. Paul (17) Spiritual Worship (7.01.2009)," in The Audiences of His Holiness Benedict XVI (Vatican City: Libreria Editrice Vaticana, 2013): "In his heart the grievous mass of evil perpetrated by humanity is dissolved and life is renewed."

${ }^{37}$ Benedict XVI, "Homily Eucharistic Celebration for the Sick (Esplanade in front of the Basilica of Notre-Dame du Rosaire, Lourdes, 15.9.2008)," in The Homilies of His Holiness Benedict XVI (Vatican City: Libreria Editrice Vaticana, 2013): "Yesterday we celebrated the Cross of Christ, the instrument of our salvation, which reveals the mercy of our God in all its fullness. The Cross is truly the place where God's compassion for our world is perfectly manifested."

${ }^{38}$ Benedict XVI, "Audience (30.05.2012)," in The Audiences of His Holiness Benedict XVI (Vatican City: Libreria Editrice Vaticana, 2013): "In the event of the Crucifixion he offers us the measure of his love which does not count the cost and knows no bounds [...]". BENEDICT XVI, "Homily Penitential Celebration with the Youth of the Diocese of Rome in Preparation for the 22 ${ }^{\text {nd }}$ World Youth Day (29.03.2007)," in The Homilies of His Holiness Benedict XVI (Vatican City: Libreria Editrice Vaticana, 2013): "Yes, the Cross reveals the fullness of God's love for us."

${ }^{39}$ Benedict XVI, "Homily Celebration of Vespers with the Faithful of Aosta (Cathedral of Aosta, Italy; 24.06.2009)," in The Homilies of His Holiness Benedict XVI (Vatican City: Libreria Editrice Vaticana, 2013): "To forgive is not to ignore, but to transform."

${ }^{40}$ Benedict XVI, "Homily Penitential Celebration with the Youth of the Diocese of Rome in Preparation for the 22 $2^{\text {nd }}$ World Youth Day (29.03.2007)," in The Homilies of His Holiness Benedict XVI (Vatican City: Libreria Editrice Vaticana, 2013): "In fact a meeting around the Cross, a celebration of the mercy of God which each one of you will be able to experience personally in the Sacrament of Confession."

${ }^{41}$ Benedict XVI, “Audience Year for Priests (St. Peter's Square, 24.06.2009)," in The Audiences of His Holiness Benedict XVI (Vatican City: Libreria Editrice Vaticana, 2013): “[...]
} 
gifts of divine mercy is a pastor, a shepherd after God's own heart. ${ }^{42}$ Every Pastor is a means through which Christ comes and loves men, manifesting the "infinite mercy of God with the reassuring words of hope."43

The power of mercy over evil takes place through conversion in the heart of man. Conversion is an uninterrupted task for the entire Church, which constantly walks the path of penance. ${ }^{44}$ By listening to the invitation to conversion (particularly during Lent), God's mercy triumphs and his friends are showered with countless favors. ${ }^{45}$ The biblical readings of Lent, in particular, remind man that God's mercy is destined for man, since His love is "obstinate" in the face of man's sin. ${ }^{46}$ Such conversion is possible because God is rich in mercy; his mercy regenerates man, creating him anew with a pure heart, renewing within him a firm spirit and granting him the joy of salvation. ${ }^{47}$ Such conversion is not a human work; it rather is the result of man's heart moved by grace to respond to the merciful love of God who loves man first.

Other aspects of Pope Benedict's teaching about Divine Mercy flow from his audiences upon the Psalms. By praying the Psalms, one remembers one's own creaturely status and need for salvation offered by the Father, sparked by con-

they feel constantly and profoundly the responsibility of their mission, which is the sign and presence of God's infinite mercy."

${ }^{42}$ Benedict XVI, “Audience Year for Priests (St. Peter's Square, 1.07.2009)," in The Audiences of His Holiness Benedict XVI (Vatican City: Libreria Editrice Vaticana, 2013): "He [St. John Vianney] used to like to say that «a good shepherd, a pastor after God's heart, is the greatest treasure which the good Lord can grant to a parish, and one of the most precious gifts of divine mercy»"."

${ }^{43}$ Benedict XVI, “Audience Munus regendi (St. Peter's Square, 26.05.2010)," in The Audiences of His Holiness Benedict XVI (Vatican City: Libreria Editrice Vaticana, 2013).

${ }^{44}$ Benedict XVI, "Audience Ash Wednesday (Paul VI Audience Hall, 9.03.2011)," in The Audiences of His Holiness Benedict XVI (Vatican City: Libreria Editrice Vaticana, 2013). Cf. Catechism of the Catholic Church (United States Catholic Conference 1997), nr. 1428.

${ }^{45}$ Benedict XVI, "Homily Holy Mass, Blessing and Imposition of the Ashes (Basilica of St. Sabina, 25.02.2009)," in The Homilies of His Holiness Benedict XVI (Vatican City: Libreria Editrice Vaticana, 2013): "God's promise is clear: if the people will listen to the invitation to conversion, God will make his mercy triumph and his friends will be showered with countless favours."

${ }^{46}$ Benedict XVI, "Homily Pastoral Visit to the Roman Parish of "Dio Padre Misericordioso" (26.03.2006)," in The Homilies of His Holiness Benedict XVI (Vatican City: Libreria Editrice Vaticana, 2013): "despite our unworthiness, God's infinite mercy is destined for us. God loves us in a way that we might call «obstinate» and enfolds us in his inexhaustible tenderness."

${ }^{47}$ Benedict XVI, "Homily Holy Mass, Blessing and Imposition of the Ashes (Basilica of St. Sabina, 25.02.2009)," in The Homilies of His Holiness Benedict XVI (Vatican City: Libreria Editrice Vaticana, 2013): "And this conversion is possible because God is rich in mercy and great in love. His is a regenerating mercy that creates within us a pure heart, renews in our depths a firm spirit, restoring the joy of salvation (cf. Ps 51 [50]:14)." 
templation of the greatness of God's mercy ${ }^{48}$ Creation is the foundation of all the saving works of God and is the first sign of hesed or Divine Mercy ${ }^{49}$ Only within creation is hesed revealed in the history of the Chosen People. As such, this first revelation of divine love is open to all,${ }^{50}$ because man is capable of rising from the "works of creation to the greatness of God and to his loving mercy." 51 But even prior to creation is the choice of God for man in Christ. ${ }^{52}$ The entirety of salvation history, as the plan of love that is revealed fully in Jesus Christ, is the manifestation of the "merciful will of God." 53

The Kingdom of God in Psalm 145 is one of mercy and compassion: "the place where compassion, love, goodness, grace and justice are manifested," a kingdom wherein evil is definitively removed. ${ }^{54}$ In Psalm 135, mercy is a legitimate but limited translation of the original Hebrew hesed, which describes attitudes that flow from a covenantal relationship. ${ }^{55}$ Another gift of God's eternal love and mercy for Israel was the gift of land, which the people were to "receive" but without "ever taking possession of it, continuing to live in an attitude of grateful acknowledgement and gratitude." ${ }_{56}$ Such grateful remembrance is of key importance in relation to Divine Mercy: in sal-

\footnotetext{
${ }^{48}$ Benedict XVI, “Audience (St. Peter's Square, 22.06.2011)," in The Audiences of His Holiness Benedict XVI (Vatican City: Libreria Editrice Vaticana, 2013).

${ }^{49}$ Benedict XVI, “Audience The Great Hallel Psalm 136 (135) (19.10.2011)," in The Audiences of His Holiness Benedict XVI (Vatican City: Libreria Editrice Vaticana, 2013).

${ }^{50}$ Benedict XVI, “Audience Psalm 135, 1-9 «His Mercy endures for ever!» Evening Prayer - Monday of Week Fourth (9.11.2005)," in The Audiences of His Holiness Benedict XVI (Vatican City: Libreria Editrice Vaticana, 2013).

${ }^{51}$ Benedict XVI, "Audience Psalm 135, 1-9,": "Great are the works of the Lord'; but this grandeur that we see in Creation is surpassed by the greatness of his mercy [...] «His compassion is greater than all his works». Mercy [...] fills the heavens, fills the earth [...]" (St. Peter Chrysologus, 42, 4-5: Sermoni 1-62bis, Scrittori dell'Area Santambrosiana, 1, Milan-Rome, 1996, pp. 299, 301)."

${ }^{52}$ Benedict XVI, "Audience Year of Faith. God reveals his «benevolent purpose» (Paul VI Audience Hall, 5.12.2012)," in The Audiences of His Holiness Benedict XVI (Vatican City: Libreria Editrice Vaticana, 2013); BenEDICT XVI, “Audience Psalm 135, 1-9,".

${ }^{53}$ Benedict XVI, "Audience (20.6.2012)"; Benedict XVI, "Audience Psalm 135, 1-9": "Mystery," for believers, is not so much the unknown as rather the merciful will of God, his plan of love which was fully revealed in Jesus Christ [...]."

${ }^{54}$ Benedict XVI, "Audience Psalm 145[144]:1-13 «I will give you glory!» Vespers of Friday of the Fourth Week (1.2.2006)," in The Audiences of His Holiness Benedict XVI (Vatican City: Libreria Editrice Vaticana, 2013); Benedict XVI, "Audience Psalm 135, 1-9."

${ }^{55}$ Benedict XVI, "Audience Psalm 135, 1-9": "[...] faithfulness, loyalty, love, and of course, God's mercy. We have here a concise summary that portrays the deep, personal bond established by the Creator with his creature."

${ }^{56}$ Benedict XVI, “Audience The Great Hallel Psalm 136 (135) (19.10.2011)," in The Audiences of His Holiness Benedict XVI (Vatican City: Libreria Editrice Vaticana, 2013).
} 
vation history, the fundamental structure of faith and worship is that of remembering the Lord's goodness and mercy, particularly in times of difficulty and distress. ${ }^{57}$ Israel remembers that, during times of humiliation, God came in times of hunger, wretchedness, confirming His identity as Creator. ${ }^{58}$ If one is immersed in darkness today, remembrance of the past helps one have hope that tomorrow, God will bring salvation..$^{59}$ For instance, when God seems not to respond to the plight of the psalmist in Psalm 22, the psalmist recalls the merciful works of the Lord that reveals His love throughout salvation history: "the whole of biblical history is a history of a cry for help on the part of the People and of saving answers on the part of God... The Lord went to the rescue, he saved the poor man and showed his merciful face." 60

Mary is an example of this ability to remember God's merciful action in salvation history, as sung in her canticle of praise, the Magnificat. ${ }^{61}$ By gratefully remembering God's merciful action, she makes it ever present. Faith and hope in His mercy are nourished by the discovery and memory of the fidelity and mercy of God in salvation history. There is, on the other hand, the danger of remembering the evils suffered without the memory of the good. It is important to reawaken the memory of His goodness and mercy revealed in the past. ${ }^{62}$

Psalm 130 is also a psalm of Divine Mercy, wherein the psalmist experiences reverent awe that flows not from punishment or fear but from forgiveness. God is not an inexorable sovereign, but rather a loving father, quick to forgive. ${ }^{63}$ Having

${ }^{57}$ Benedict XVI, “Audience The Great Hallel Psalm 136 (135)": "This is also important for us: to remember the Lord's goodness. Memory strongly sustains hope."

${ }^{58}$ Benedict XVI, "Audience Psalm 135, 10-26."

${ }^{59}$ Benedict XVI, "Audience The Great Hallel Psalm 136 (135)."

${ }^{60}$ Benedict XVI, “Audience Psalm 22 (21): «My God, my God, whey have you forsaken me?» (Paul VI Audience Hall, 14.09.2011)," in The Audiences of His Holiness Benedict XVI (Vatican City: Libreria Editrice Vaticana, 2013).

${ }^{61}$ BenEDICT XVI, "Audience Year of Faith. The stages of Revelation (Paul VI Audience Hall, 12.12.2012)," in The Audiences of His Holiness Benedict XVI (Vatican City: Libreria Editrice Vaticana, 2013); Benedict XVI, “Audience Psalm 22 (21)": "Mary exalts God's merciful action in the actual journey of his people, his fidelity to the promises of the covenant that he made to Abraham and his descendents; and all this is a living memory of the divine presence that is never absent (cf. Lk 1:46-55)."

${ }^{62}$ Benedict XVI, "Audience Psalm 135, 10-26": "Our danger is that the memory of evil, of the evils suffered, may often be stronger than the memory of good. The Psalm's purpose is also to reawaken in us the memory of good as well as of all the good that the Lord has done and is doing for us, which we can perceive if we become deeply attentive. It is true, God's mercy endures for ever: it is present day after day."

${ }^{63}$ Benedict XVI, "Audience Psalm 130[129] «Lord, hear my voice!» Evening Prayer - Sunday of Week Fourth (19.10.2005)," in The Audiences of His Holiness Benedict XVI (Vatican City: Libreria Editrice Vaticana, 2013). 
experienced mercy himself, the psalmist then turns to God in prayer for the entire community. This role of intercessory prayer - grounded in trust in Divine Mercy - is manifest in Abraham's intercession for Sodom and Gomorrah. Abraham begs for God's mercy on the guilty on the basis of the innocent who dwell in the city. Intercession attempts to prevent the spread of evil not through the avoidance of punishment but by being delivered from the evil that is within man. ${ }^{64}$ God Himself became the one innocent person in Jesus Christ, so that the prayer of Abraham could be effective in saving all the guilty through the innocence of One. ${ }^{65}$

Those who pray can have the certainty of being heard and answered because God is "Love and infinite Mercy." to God, by meditating upon God's definitive "yes" to man. ${ }^{67}$ Prayer enables man to be in "love with the Lord" so as to then be capable of bringing his merciful love to His People. ${ }^{68}$ The attitude proper to prayer is the "same attitude of mercy and love with which God treats us," ${ }^{69}$ an attitude that is to then be extended to the rest of our lives. For the one word "mercy" includes more than those listed in the traditional works of mercy: "The field of works of mercy is immense." 70 The mission of all Christians is to proclaim and witness to the message of hope: that the

\footnotetext{
${ }^{64}$ Benedict XVI, “Audience (St. Peter's Square, 18.05.2011)": "The smaller the number becomes, the greater God's mercy is shown to be [...] It is not punishment that must be eliminated but sin, the rejection of God and of love which already bears the punishment in itself [...]".

${ }^{65}$ Benedict XVI, “Audience (St. Peter's Square, 18.05.2011),” in The Audiences of His Holiness Benedict XVI (Vatican City: Libreria Editrice Vaticana, 2013): "The prayer of intercession of Abraham, our father in the faith, teaches us to open our hearts ever wider to God's superabundant mercy so that in daily prayer we may know how to desire the salvation of humanity and ask for it with perseverance and with trust in the Lord who is great in love."

${ }^{66}$ Benedict XVI, "Audience Prayer in the second part of the Book of Revelation (Rev. 4:122:21) (Paul VI Audience Hall; 2.09.2012)," in The Audiences of His Holiness Benedict XVI (Vatican City: Libreria Editrice Vaticana, 2013).

${ }^{67}$ Benedict XVI, “Audience (St. Peter's Square, 30.05.2012)," in The Audiences of His Holiness Benedict XVI (Vatican City: Libreria Editrice Vaticana, 2013): "In our prayers we are called to say «yes» to God, to respond with this «amen» of adherence, of faithfulness to him throughout our life. We can never achieve this faithfulness by our own efforts; it is not only the fruit of our daily striving; it comes from God and is founded on the «yes» of Christ who said: my food is to do the will of the Father (cf. Jn 4:34)."

${ }^{68}$ Benedict XVI, "Audience Saint Pius the Tenth (Castel Gandolfo, 18.08.2010)," in The Audiences of His Holiness Benedict XVI (Vatican City: Libreria Editrice Vaticana, 2013): "Only if we are in love with the Lord shall we be able to bring people to God and open them to his merciful love and thereby open the world to God's mercy."

${ }^{69}$ Benedict XVI, "Audiences (Paul VI Audience Hall, 15.02.2012)," in The Audiences of His Holiness Benedict XVI (Vatican City: Libreria Editrice Vaticana, 2013): "and he invites us to live in our prayers the same attitude of mercy and love with which God treats us; "forgive us our trespasses and forgive those who trespass against us», we say every day in the Lord's Prayer."

${ }^{70}$ Benedict XVI, "Audience Ash Wednesday."
} 
merciful Father calls man to be his son and overcome every form of violence and hatred and contribute to the definitive triumph of love. ${ }^{71}$

The Gospel is God's grace given to the sinner, as manifest in the example of the tax collector who has humble trust in Divine Mercy. A sign of God's mercy in Jesus is precisely that He does not exclude anyone from his friendship. The figure of Matthew provides a paradox for contemplation: those farthest from holiness can become a model of accepting God's mercy and provide a glimpse of the marvelous effects of His mercy in their lives. The Lord does not exclude anyone from His call: Jesus calls people of low social class while they go about their ordinary work. ${ }^{72}$ Even though He is exalted, He looks on the lowly with affection and kindness, for He chooses to take the side of the weak, victims, and the lowliest. ${ }^{73}$ His mercy is thus manifest in His nearness and closeness, manifest in Jesus' encounter and dialogue with all, helping man to leave sin behind by hearing His call and entering into communion with Him. In Jesus, God waits for man, seeks Him out, welcomes him into communion, gives man fullness of life, hope, and peace. The encounter with Jesus gives man His consolation in the storms of life and enables man to live a life full of joy and goodness. ${ }^{74}$

Help to the poor is one of the primary means of imitating God's mercy in everyday life. ${ }^{75}$ Pope Benedict entrusted the "Flame of Mercy" to the crowds of youth in Poland, so that they themselves might become "heralds of Love and Divine Mercy in the world." 76 He recommended to newly weds to be open to the needs

${ }^{71}$ Benedict XVI, "Apostolic Journey to Munich, Altotting and Regensburg (St. Peter's Square, 20.09.2006)," in The Audiences of His Holiness Benedict XVI (Vatican City: Libreria Editrice Vaticana, 2013).

${ }^{72}$ Benedict XVI, “Angelus (Castel Gandolfo, 20.08.2006)," accessed 15.11.2019, in http:// w2.vatican.va/content/benedict-xvi/en/angelus/2006/documents/hf_ben-xvi_ang_20060820.html.

${ }^{73}$ Benedict XVI, "Audience Psalm 138[137] Judaic hymn of thanksgiving. Evening PrayerTuesday of the Fourth Week (7.12.2005)," in The Audiences of His Holiness Benedict XVI (Vatican City: Libreria Editrice Vaticana, 2013): "Thus, one discovers that God is certainly «exalted» and transcendent, but he looks on the «lowly» with affection while he turns his face away from the proud as a sign of rejection and judgment [...]."

${ }^{74}$ BenEDict XVI, "Audience (St. Peter's Square, 30.05.2012)": "Prayer is the encounter with a living Person to listen to and with whom to converse; it is the meeting with God that renews his unshakeable fidelity, his «yes» to man, to each one of us, to give us his consolation in the storms of life and to enable us to live, united to him, a life full of joy and goodness, which will find fulfilment in eternal life."

${ }^{75}$ Benedict XVI, “Audience St. Gregory Nazianzus (2) (Paul VI Audience Hall, 22.08.2007)," in The Audiences of His Holiness Benedict XVI (Vatican City: Libreria Editrice Vaticana, 2013): "Make yourself God for the unfortunate, imitating God's mercy (St. Gregory Nazianzus, Orationes 14, 26 De Pauperum Amore: PG 35, 892bc)."

${ }^{76}$ Benedict XVI, "Audience Apostolic Journey to Poland "Stand firm in your faith!» (31.05.2006)," in The Audiences of His Holiness Benedict XVI (Vatican City: Libreria Editrice Vaticana, 2013). 
of brothers and sisters. ${ }^{77}$ In families, there ought to be a capacity for listening and for dialogue, for mutual understanding and love, so as to be a sign for each other of God's merciful love. ${ }^{78}$ "As can be seen, the Magisterium of Pope Benedict XVI on Divine Mercy touches on many aspects of the Gospel and the life of the Church, as a fundamental value for every Christian."

\section{ANALYSIS OF THE TEACHING OF POPE FRANCIS ON MERCY}

Unlike Pope Benedict XVI, Pope Francis has provided the Church with two apostolic letters that specifically refer to mercy, namely, Misericordiae Vultus and Misericordia et Misera. These two documents form the basis for the examination of his papal magisterium on Divine Mercy, as the examination of mercy in all of his homilies and audiences would require greater length than is permitted here.

In Misericordiae Vultus,${ }^{79}$ Pope Francis emphasizes that Jesus is the face of the Father's Mercy. His mission was that of fully revealing divine love and mercy in a visible, tangible manner, as the beating heart of the Gospel. For His entire person - in all His words and actions - reveals a love given freely: the mystery of Christ is a mystery of the merciful love of God. The Church introduces all into the mystery of divine mercy through the contemplation of the face of Christ. In doing so, the Church is a faithful witness of mercy, confessing and living mercy as the essence of the revelation given in Jesus Christ (MV 25). "Mercy" is the synthesis of the entirety of the Christian faith, for it reveals the Trinity and is itself the greatest act in which God Himself comes to meet man in Jesus Christ. Mercy reveals the fundamental truth that man is eternally loved by God: man is loved without limit despite his limitations and sins (MV 2).

Christians need to constantly contemplate the mystery of mercy in Jesus Christ, since it is the source of joy, peace and meaning as well as a necessity for

${ }^{77}$ Benedict XVI, "Audience Ash Wednesday (Paul VI Audience Hall, 22.02.2012)," in The Audiences of His Holiness Benedict XVI (Vatican City: Libreria Editrice Vaticana, 2013): "Lastly, may works of mercy help you, dear newlyweds, while living your married life, to open it to the needs of your brothers and sisters."

${ }^{78}$ Benedict XVI, "Audience Year of Faith. How to speak about God? (Paul VI Audience Hall, 28.11.2012)," in The Audiences of His Holiness Benedict XVI (Vatican City: Libreria Editrice Vaticana, 2013): "Lastly, the capacity for listening and for dialogue: the family must be a milieu in which we learn to be together, to settle disagreements in conversation with each other, which consists in listening and speaking, in mutual understanding and love, so as to be a sign for each other of God's merciful love."

${ }^{79}$ Francis, Apostolic Letter Misericordiae Vultus (Vatican City: Libreria Editrice Vaticana, 2015). From here forward, it will be abbreviated by MV in the text. 
salvation. The Holy Spirit enables the faithful to contemplate His face of mercy, guiding their footsteps to cooperate in Christ's work of salvation (MV 4). By such contemplation, the faithful share in His mercy and so are moved to act to help others as did Jesus (MV 8). Silence is necessary to meditate upon the Word of God that reveals mercy and strengthens man to adopt mercy as his own manner of life (MV 13).

The opening day of the Holy Year on December 8 reminds the faithful of the Immaculate Conception, namely, the manner in which God reveals His Mercy: God responds to man's sin with the fullness of forgiveness, showing that mercy is always greater than man's sin (MV 3). December 8 also reminds the faithful of the work of the Holy Spirit, that brought about a new stage of evangelization in Vatican II, so that the Church would be a living sign of the Father's love in the world (MV 4). The new evangelization ought to express itself in and through mercy: the very language and activity of the Church ought to be that of mercy. For the first truth of the Church is the love of Christ that is expressed through forgiveness and give of self in service of man (MV 12). The Year of Mercy is given so that Christians ourselves become more aware and receptive of Divine Mercy and so become an effective sign of the Father, in imitation of Jesus (MV 3). The credibility of the Church, in fact, is confirmed by her living and offering Divine Mercy. The Church lives her mission authentically when she proclaims mercy and so leads the faithful to draw near to the fount of mercy in the Savior (MV 11).

The pastoral activity of the Church ought to be imbued with mercy (MV 10). The Church ought to make her own the attitude of the Son of God, going to encounter each person and passing by no one. This attitude of mercy is expressed through such qualities and attitudes as goodness, tenderness, closeness, patience, compassion, patience, compassion, forgiveness, indulgence, deep emotion, generosity, warmth, and kindness. Where the Church is, the mercy of the Father ought to be visible. Wherever Christians are, there must be found oases of mercy (MV 12), for the balsam of mercy is the distinctive sign of the Kingdom of God (MV 5). The calling of Matthew forms a particularly tangible manifestation of mercy and conversion on account of the merciful gaże of Jesus (MV 8). One ought not judge or condemn, to not look upon one's neighbor only on the surface but like God to gaze into the depths of the other with love (MV 14).

Mercy forms the basis for Christian morality, since it is the fundamental law that dwells in the heart of each person (MV 2). Mercy is thus not only the primary characteristic of the Father and His salvific activity in salvation history; mercy is also the criterion that reveals His true children. Each Christian is thus called 
to a life of mercy precisely because Christians are privileged to experience His mercy. Mercy is thus presented by Christ as the criterion for verifying the credibility of our faith (Matt 5:7, MV 9). If mercy is the keyword that describes God's manner of treating man, then the same is to be true as to how man treats his fellow man. Just as God does not limit himself to declaring His love but rather reveals it visibly and tangibly in Jesus Christ, so each Christian is to manifest mercy in his concrete, daily life: in his intentions, behavior, and attitudes of everyday life. Just as the Father loves, so also the children ought to love (MV 9). Forgiveness is the most evident manner to express mercy.

Mercy is the visible revelation of how God loves: He offers all of Himself, always, in freedom, without asking for anything in return. He comes to assist us in our needs, granting us His presence, nearness, and compassion (MV 14). In turn, Christians are themselves to go to the furthest existential peripheries to aid people living there with mercy through solidarity that uproots cynicism and indifference to their pain. The corporal and spiritual works of mercy serve to reawaken one's conscience in the face of poverty and to the reality of the Gospel, which is directed in a privileged manner to the poor. In the broken bodies of the poor, one touches the Body of Christ who is again visible in their suffering (MV 15).

Mercy is not merely some abstract idea, but a concrete fact, through which God reveals His merciful love, a love that is similar to that of a father or mother that watches over their child. Quoting Psalm 136, the Pope emphasizes that all of man's history, as well as eternity, remains under the gaze of the merciful Father. Jesus Himself used this Psalm to indicate the meaning and purpose of His own death as a mystery of love and mercy. The refrain, "for His mercy endures forever," ought become a refrain for each Christian in their daily life (MV 7). Lent is to be a time of particular celebration, meditation, and experience of mercy (MV 17).

Priests ought to be living instruments of mercy in the confessional. Priests are to not only welcome the prodigal son but ought to seek out the older son as well, to invite him to the banquet (MV 17). A concrete expression of seeking both brothers was the institution of the missionaries of mercy (MV 18) and his appeal to the mafia to cease their crime (MV 19).

Justice and mercy are not two opposites or contradictory attributes; rather, they are two aspects of the same reality that reaches its climax in love. Mercy does not oppose justice but rather offers to sinners the opportunity for conversion. Justice is referred to primarily in reference to society, as giving each what is his due. In the Bible justice is rather an entrustment of oneself to the will of God. Jesus, for his part, emphasizes the significance of faith more than the keeping of the Law. Justice as keeping the Law brings about division of people between the just and 
sinners. Jesus, on the other hand, reveals the gift of mercy that seeks sinners and helps those in need on account of their innate human dignity. The rule of life given to the disciples by Jesus depends upon mercy, which is the most basic element in the mission of Jesus (MV 20).

It is easier for God to hold back anger than to hold back mercy, since the anger of God remains only a moment, while His mercy endures forever. For the one who commits evil deserves not only punishment but also the opportunity for conversion and forgiveness. For the end of the Law is Christ, and divine justice is the mercy offered to all as grace flowing from the death and resurrection of Christ. The Cross is thus the definitive judgement of God on the world, since it offers man the certainty of love and of new life (MV 21).

Judaism and Islam also experience the divine closeness and support in daily weaknesses and difficulties. The Pope recommends greater openness to dialogue as well as the elimination of all forms of closed mindedness and pride, as well as violence and discrimination (MV 23).

Mary, Mother of Mercy, accompanies man and enables him to experience the joy of God's tenderness. She entered into the depths of Divine Mercy and obtains for man the grace to live always in the light of divine forgiveness and in unshakable trust in His Love (MV 24).

The title Misericordia et Misera ${ }^{80}$ comes from the words that St. Augustine used to describe the encounter of Jesus with the adulteress, a meeting of two persons rather than two abstract ideas of sin and mercy. There, Jesus reveals the original goal of the Law: its center is the love of God, which must have priority over all else. Jesus' judgment on the woman flows from His pity and compassion for the sinner. The experience of mercy and forgiveness enables man - amid his weakness and $\sin$ - to look beyond sin and live differently (MM 1).

Forgiveness is the most visible sign of the Father's love, a love that Jesus desired to reveal by His entire life and death. His forgiveness embraces the sinner in all his sinfulness; as such, no one can place conditions upon Divine Mercy, which is always an act of unconditional and unmerited love of the Father. No one ought to limit its power. Mercy is thus the concrete act of love which forgives, transforms, and changes one's life (MM 2). This experience of mercy brings about joy; one ought not permit sadness and worry to take away joy, so that one can look at daily life with peace. Modern culture, dominated ever more by technology, has more and more forms of sadness and isolation. The future seems to be uncertain, and so even the youth have the experience of sadness, melancholy, and boredom

${ }^{80}$ Francis, Apostolic Letter Misericordia et Misera (Vatican City: Libreria Editrice Vaticana, 2016). From here forward, it will be abbreviated by MM in the text. 
that can slowly lead to despair. There is a need therefore for witnesses of hope and true joy centered in the joy of experiencing mercy (MM 3).

Mercy ought to continually be celebrated and experienced in the Church, beyond the Jubilee, since mercy is the very life of the Church, making the truth of the Gospel both visible and tangible. Everything is revealed in mercy and occurs in the merciful love of God. The Church needs to be daily shaped and transformed by the renewing power of mercy. The prayer of the Church for mercy is efficacious: when one prays for such mercy, it is granted. When one confesses such mercy as real and living, it has the power to transform. This occurs first through the celebration of mercy which takes place in the Eucharistic celebration, which is itself a dialogue of prayer between the community and the heart of the Father, who rejoices to pour out His merciful love. The penitential rite, as well as the collects, the Eucharistic prayers speak of His mercy: each moment of the Eucharistic celebration can be understood in light of mercy. In the Mass, Christians witness the dialogue between God and His people in His Word. In the readings, Christians witness the ceaseless work of mercy, in which God calls us His friends to accompany us and show us the path to life. The Word shows us His closeness and response to our needs. The Bible relates the miracles of Divine Mercy; each part is imbued with the love of the Father. Through the Word, the Lord continues to speak to His Bride. The Pope desires that the Word of God be ever more venerated, so that one can better understand the mystery of love, which flows from the source of mercy (MM 5-6). The Holy Father instituted the third Sunday of Ordinary Time to be dedicated entirely to the Word of God. ${ }^{81}$

The condition for the credibility of priesthood is the ability to convey the certainty that God loves us. For the most basic content of faith is that before there is the revelation about sin that is the revelation of love with which God created the world and man. Love is the first act, through which God can be known and comes to encounter man. Divine love and mercy always precede man, accompanying him and remaining with him, even in $\sin (\mathrm{MM}$ 6). Lectio divina on the Word ought to show the faithful how fecund the text is, particularly on topics of mercy. Such meditation ought to bring about concrete actions and works of mercy (MM 7). ${ }^{82}$ Mercy by its very nature tends to become visible and tangible in concrete, dynamic action. The works of mercy touch the entirety of man's life; thus, the Church must find new forms of mercy, since mercy itself is excess that always is creative and goes further. The Church cannot be indifferent to the poverty of so many but must go out to meet

${ }^{81}$ Cf. "Motu Proprio, Aperuit Illis," accessed 15.11.2019, in http://w2.vatican.va/content/ francesco/en/motu_proprio/documents/papa-francesco-motu-proprio-20190930_aperuit-illis.html.

${ }^{82}$ Cf. Benedict XVI, Apostolic Exhortation Verbum Domini, nr. 86-87; Francis, Motu Propio Aperuit Illis, nr. 13. 
men in every form of poverty that they encounter. Christians are to discover anew the joy of sharing and the beauty of solidarity. For that reason, the Pope instituted the $33^{\text {rd }}$ Sunday of Ordinary Time as the World Day of the Poor. Poverty is found in the very center of the Gospel, as the Word of God calls man to leave behind indifference and individualism. Such concern for the poor is an authentic manner of living the new evangelization and of promoting social justice and peace (MM 21).

Two other sacraments, penance and anointing of the sick, convey mercy in a particular way to believers. The Father's mercy is experienced in a particular way in the sacrament of Penance as the embrace of the Father: there, man experiences the fullness of His love in the face of our sinfulness, where grace is proven more powerful than sin. Penance thus ought to find anew its central place in Christian life. As a concrete sign of mercy in regard to the sacrament of penance, Pope Francis granted continued privileges to the missionaries of mercy as well as to all priests to forgive the sin of abortion, as well as faculties to priests of the Society of St. Pius X (MM 8-12, 15).

The family is the privileged place to live mercy, and pastoral efforts are to be made to show the great value of family life. ${ }^{83}$ The experience of mercy enables each person to know that his or her life - with all its joys, sorrows, and unique aspects - takes place under the mercy of God. The moment of death is a moment of mercy that requires the presence of others, so as to become the final act of love toward God and others. Pope Francis connects mercy with comfort (cf. Is 40:1). Mercy is expressed through the human qualities of closeness, tenderness, and support: drying the tears, breaking open the cycle of loneliness. The key is to be with those who suffer, to show them that the love of God is stronger than their pain. This can be expressed even without words: through gestures and acts of love, sharing the suffering of another (MM 13-14).

Christians are not to leave mercy as a beautiful, but lifeless idea. The danger of creating a "theory of mercy" is conquered only by daily living of mercy. The Holy Spirit enables Christians to be ready to make an effective and selfless contribution to the work of mercy. Christians are to create a culture of mercy, wherein there are millions of ways to express mercy. The culture of mercy is formed through prayer, in obedient openness to the Holy Spirit, in knowledge of the lives of the saints and in concrete closeness to the poor. We are never to "hold onto" what we have received, but to share with the poor the gifts received (MM 20-21).

Mercy renews and accomplishes redemption, since it is the encounter between two hearts: the heart of God which goes out to meet the heart of man, changing man's heart from a stony heart to that of flesh. Mercy thus brings forth joy and hope for a new life.

${ }^{83}$ Cf. Francis, Apostolic Exhortation Amoris Laetitia (Vatican City: Libreria Editrice Vaticana, 2016), where mercy is found up to 37 times, and merciful three times. 
Such joy is experienced each time man asks for forgiveness. Man becomes a new creation, having experienced mercy, and so becomes an instrument of mercy (MM 16).

\section{THE IMPORTANCE OF THEIR PAPAL MAGISTERIUM FOR THE UNDERSTANDING AND IMPLEMENTATION OF THE VENERATION OF DIVINE MERCY}

The foregoing comparison of papal magisterium provides the foundation to examine the forms of worship of Divine Mercy that flow from such teaching. The basic pattern for experiencing and living mercy is that of meditation (particularly upon the Word of God in silent, personal prayer), participation in the liturgy and the sacraments, the transformation of attitudes, and concrete works of mercy. That is, the first element of worship of Divine Mercy is a greater veneration for the centrality Word of God. All of salvation history - beginning with creation, continuing in the history of the Chosen People, reaching its climax in Jesus Christ, and extending into the Church - is a continuous revelation of Divine Mercy. Each Christian is to meditate not only upon the written words of the Gospel but upon the Face of Christ, the Face of Mercy. ${ }^{84}$

Mercy becomes a prism through which everything is seen in the light of faith: faith in God's merciful love that is first, before sin, and becomes the primary norm for action in daily life. Divine Mercy is the nucleus and beating heart of the Gospel. As there is a hierarchy of revealed truth, so there is a hierarchy in which Divine Mercy is revealed. The Cross is the climax of Divine Mercy offered to the sinner, where sin is definitively conquered by mercy. The role of such personal prayer is to remember how Divine Mercy has already been manifested in salvation history, so as to enable it to be present to Christians today. The height of the presence of Divine Mercy as well as worship of Divine Mercy - is found in the liturgy, in which the prayer of the Church not only remembers such mercy but makes it efficaciously present. All of the sacraments are the primary points of reference for the worship of Divine Mercy.

In both of the teaching of the Popes, there is an attempt to rediscover the basic elements of the faith and life of the Church in light of the merciful love of God. Whereas Pope Benedict more often speaks of caritas, Pope Francis more often mentions the word mercy. In addition, he more clearly wants mercy to not remain a theory or ideology by bearing fruit in the transformation of attitudes and in creative works of mercy. That is, Pope Francis is more clearly intent upon finding ever new ways of living and expressing Divine Mercy; there is no limit to the works of mercy. This living of mercy thus is to help create a culture of mercy. The goal of Pope

\footnotetext{
${ }^{84}$ Cf. John Paul II, Apostolic Letter Rosarium Virginis Mariae, nr. 1, 3, 10, etc., on the Rosary as contemplation of the face of Christ with Mary.
} 
Francis in the year of mercy was precisely to help Christians experience Mercy in a particular manner so as to give ever stronger witness to it.

One thus cannot find in the teaching of Pope Benedict support for the addition of five new mysteries of the Rosary, since all the mysteries of the Rosary are already mysteries of mercy. Whereas the mysteries of the public life of Jesus were missing without the Luminous Mysteries, it is not true that mysteries of mercy would be lacking without the addition of new mysteries of mercy. Moreover, the addition of such mysteries - without proper instruction - could shift the focus away from the central mysteries of mercy (namely, the Incarnation and Paschal Mystery) to secondary mysteries (e.g., a particular moment of Jesus' life and ministry). Notable, too, is Pope Benedict's choice to give his Wednesday audiences on the Psalms, to teach Christians how to pray the Psalms, since the Rosary originally was intended as a manner of prayer for those who could not pray them. Whereas Pope Benedict writes and speaks as a dogmatic theologian, Pope Francis is more focused upon the volitional, emotional aspects of living the Christian faith in everyday life. There is thus support in terms of pastoral conversion and creativity for such an addition so as to build up the imagination of mercy so as to then put that mercy into action.

\section{CONCLUSION}

In regard to the proposal to add mysteries of mercy, it is important to emphasize that all of salvation history - as well as the already existing mysteries of the Rosary - reveal Divine Mercy. A proposal to add distinct mysteries of mercy cannot be accepted on the basis of already existing papal magisterium without particular explanation and theology, so as to ensure a proper understanding of the relation of such mysteries to those that already exist, so that the intention of such a proposal come to fruition, rather than confuse the faithful or obscure the mystery of Divine Mercy in all of salvation history.

\section{BIBLIOGRAPHY}

Apostolic Penitentiary. Decree Indulgences attached to devotions in honour of Divine Mercy,

Vatican: Libreria Editrice Vaticana, 2002.

Thomas Aquinas. Summa Theologiae. London: Oates \& Washbourne, 1921.

Benedict XVI. The Audiences of Pope Benedict XVI (English). Vatican: Libreria Editrice Vaticana, 2014.

Benedict XVI. Encyclical Caritas in Veritate. Vatican: Libreria Editrice Vaticana, 2009. 
Benedict XVI. Encyclical Deus Caritas Est. Vatican: Libreria Editrice Vaticana, 2005.

Benedict XVI. The Homilies of Pope Benedict XVI (English). Vatican: Libreria Editrice Vaticana, 2013.

Benedict XVI. Apostolic Exhortation Sacramentum Caritatis. Vatican: Libreria Editrice Vaticana, 2007.

Benedict XVI. Enyclical Spe Salvi. Vatican: Libreria Editrice Vaticana, 2007.

BeNEDICT XVI, Apostolic Exhortation Verbum Domini. Vatican: Libreria Editrice Vaticana, 2010.

Catechism of the Catholic Church (Vatican: Libreria Editrice Vaticana, 1997).

Congregation for Divine Worship and the Discipline of the Sacraments. Decree Establish-

ing the Sunday after Easter "Divine Mercy Sunday.” Vatican: Libreria Editrice Vaticana, 2000.

FrancIs. Motu Propio Aperuit Illis. Vatican: Libreria Editrice Vaticana, 2019.

Francis. Apostolic Exhortation Amoris Laetitia. Vatican: Libreria Editrice Vaticana, 2016.

FrancIS. Apostolic Letter Misericordia et Misera. Vatican: Libreria Editrice Vaticana, 2016.

FrancIs. Apostolic Letter Misericordiae Vultus. Vatican: Libreria Editrice Vaticana, 2015.

Francis. The Name of God is Mercy. New York 2016.

John Paul II. Encyclical Dives in Misericordia. Vatican: Libreria Editrice Vaticana, 1980.

John PAul II. Apostolic Letter Rosarium Virginis Mariae. Vatican: Libreria Editrice Vaticana, 2002.

John PAul II. Homilies. Vatican: Libreria Editrice Vaticana, 2014.

KowalsKa, Faustina Sr. Divine Mercy in My Soul. Stockbridge: Marian Press, 1984.

Roman Missal (Washington: International Commission on English in the Liturgy, 2010).

Stackpole, Robert. Divine Mercy: A Guide from Genesis to Benedict XVI. Stockbridge:

Marian Press, 2008.

\section{KULT MIŁOSIERDZIA BOŻEGO W ŚWIETLE NAUCZANIA \\ PAPIEŻA BENEDYKTA XVI I PAPIEŻA FRANCISZKA}

\section{S T R E S Z C Z E N I E}

Dwaj ostatni papieże, Benedykt XVI i Franciszek, wzorem Jana Pawła II, akcentują w swoim nauczaniu Miłosierdzie Boże. Każdy z nich czyni to inaczej, a w związku z tym sposób oddawania czci Bożemu Miłosierdziu będzie u nich inny. Podczas gdy obydwaj papieże akcentują całość historii zbawienia, w której objawia się Miłosierdzie Boże, uwieńczone w osobie Jezusa Chrystusa, papież Franciszek częściej mówi o praktyce miłosierdzia i unika teoretyzowania. Jednym ze sposobów urzeczywistniania miłosierdzia jest propozycja dodania do różańca nowych tajemnic, które nie mają wsparcia w papieskim nauczaniu Benedykta XVI, ale znajdują poparcie w pragnieniu papieża Franciszka, by coraz bardziej przenikało ono do codziennych postaw i działań chrześcijan. Należy zadbać, aby wpisać taką zmianę sposobu oddawania czci Bożemu Miłosierdziu wraz z właściwym uzasadnieniem teologicznym, podkreślającym obecność Miłosierdzia Bożego w istniejących już tajemnicach różańca, zwłaszcza we Wcieleniu i Tajemnicy Paschalnej.

Słowa kluczowe: miłosierdzie Boże; kult; cześć; nabożeństwo; Benedykt XVI; Franciszek; różaniec. 